\title{
Physicochemical stability of an admixture of lidocaine and ketamine in polypropylene syringe used in opioid-free anaesthesia
}

\author{
Benoît Beiler, ${ }^{1}$ Damien Barraud, ${ }^{2}$ Jean Vigneron, ${ }^{3}$ Béatrice Demoré ${ }^{3,4}$
}

\begin{abstract}
${ }^{1}$ Pharmacy, Centre Hospitalier Universitaire de Nancy, Vandoeuvre-les-Nancy, France ${ }^{2}$ Burn Critical Care Unit, Centre Hospitalier Regional de MetzThionville, Metz, France ${ }^{3}$ Pharmacy, Centre Hospitalier Universitaire de Nancy, Vandoeuvre-lès-Nancy, France ${ }^{4}$ APEMAC, Vandoeuvre les Nancy, France
\end{abstract}

\section{Correspondence to} Benoît Beiler, Centre Hospitalier Universitaire de Nancy, Nancy 54000, France; benoitbeiler@yahoo.fr

Received 26 April 2019 Revised 26 August 2019 Accepted 23 September 2019 Published Online First 18 October 2019

\section{EAHP Statement 3:} Production and Compounding.

\section{RACT}

Objectives Opioid-free anaesthesia is a treatment strategy of pain management based on the use of drugs such as lidocaine, ketamine and dexmedetomidine that do not interact significantly with opioid receptors. In particular, these drugs are used by anaesthesiologists to ensure adequate levels of analgesia during surgical procedures for burn patients such as daily wound dressings and graft surgeries. Furthermore, for hypothermia prevention and wound-healing purposes, ambient temperature must be kept high for these patients, usually between $27^{\circ} \mathrm{C}$ and $30^{\circ} \mathrm{C}$. To facilitate the use of this technique, clinicians want to mix lidocaine and ketamine in the same syringe. No stability data is available to determine the feasibility of this admixture and at this temperature. The objective was to study the physicochemical stability of lidocaine $20 \mathrm{mg} / \mathrm{mL}$ with ketamine $2.5 \mathrm{mg} / \mathrm{mL}$ diluted with $0.9 \%$ sodium chloride $(0.9 \% \mathrm{NaCl})$ stored at $28^{\circ} \mathrm{C}$ in polypropylene syringe for 48 hours.

Methods Physical stability was evaluated by visual examination and by measuring turbidity with a spectrophotometer. Chemical stability was determined after preparation and after 6, 24 and 48 hours of conservation with a high performance liquid chromatography and $\mathrm{pH}$ measurements. The method was validated according to International Conference on Harmonisation Q2(R1) guidelines.

Results Both lidocaine $(99.98 \% \pm 1.44 \%)$ and ketamine $(100.70 \% \pm 0.95 \%)$ retained more than $95 \%$ of their initial concentration after 48 hours storage. $\mathrm{pH}$ measurements remained stable over the course of the study (less than 0.21 point of variation). No signs of physical instability were observed after visual and subvisual inspections.

Conclusions The physicochemical stability of lidocaine $20 \mathrm{mg} / \mathrm{mL}$ and ketamine $2.5 \mathrm{mg} / \mathrm{mL}$ diluted with $0.9 \%$ $\mathrm{NaCl}$ in a polypropylene syringe stored at $28^{\circ} \mathrm{C}$ protected from light was demonstrated for 48 hours. This infusion technique is therefore feasible from a pharmaceutical point of view in burn-unit settings.

\section{INTRODUCTION}

General anaesthesia consists in the balanced association of hypnotics, either intravenous or volatile, analgesics, mostly opioids, and neuromuscular blockers if indicated. Pain management is a major issue in the critically-ill burn patient. Moderate and severe pains are mainly relieved with the use of opioid medicines such as tramadol, morphine or oxycodone. Economic and highly effective, opioid medicines are widely prescribed for patients during the perioperative period, for chronic pain or cancer pain. However, these medications can cause constipation, nausea and vomiting, respiratory depression, hyperalgesia, drug tolerance and addiction. The last two side-effects cited lead some patients to substance misuse, which is the first step towards aberrant drug-related behaviour and thus these side-effects are the main disadvantage of opioid medications. Opioid addiction has become a major health concern in the United States, and is carefully monitored in France to avoid a similar crisis. ${ }^{12}$ In view of these considerations, prescribing other methods of pain management, whenever possible, can contribute to reduce use of opioid medicines. ${ }^{3}$

Opioid-free anaesthesia is based on the use of drugs that do not interact significantly with opioid receptors $\mu, \kappa$ and $\delta$. N-methyl-D-aspartate antagonists such as ketamine or magnesium, $\alpha-2$ agonists such as clonidine or dexmedetomidine, acetaminophen, nonsteroidial anti-inflammatory and local anaesthetics such as lidocaine are the major medicines used. ${ }^{3}{ }^{4}$ During anaesthesia, opioids can be fully replaced by these drugs. In the burn patients, for quick procedures such as daily-wound dressings, these drugs are given separately and by IV boluses. For longer procedures such as excision graft surgeries, they are given by continuous IV infusion, sometimes mixed in the same syringe, and extended for hours in the postoperative period. Furthermore, for hypothermia prevention and wound-healing purposes, ambient temperature must be kept high, usually between $27^{\circ} \mathrm{C}$ and $30^{\circ} \mathrm{C} . .^{5}$ Stability data of lidocaine mixed with ketamine is necessary in this particular situation.

Ketamine and lidocaine are both very stable drugs in solution. Stucki MC et al demonstrated 365 -day stability for $1 \mathrm{mg} / \mathrm{mL}$ ketamine, stored at $40^{\circ} \mathrm{C}$ in $0.9 \%$ sodium chloride $(0.9 \% \mathrm{NaCl})$ in polypropylene syringes. ${ }^{6}$ Huvelle $S$ et al established 180-day stability for $50 \mathrm{mg} / \mathrm{mL}$ ketamine in polypropylene syringes at $25^{\circ} \mathrm{C}$ protected from light. ${ }^{7}$ For lidocaine, Storms ML et al defined 90-day stability at $25^{\circ} \mathrm{C}$ and $20 \mathrm{mg} / \mathrm{mL}$ in polypropylene syringes and Smith FM et al described 120-day stability in glucose $5 \%$ in PVC infusion bags at $4 \mathrm{mg} / \mathrm{mL}$ at $30^{\circ} \mathrm{C}^{89}$ However, no stability data of lidocaine mixed with ketamine was available.

The objective of this work was to study the stability of lidocaine hydrochloride at $20 \mathrm{mg} / \mathrm{mL}$ mixed with ketamine hydrochloride at $2.5 \mathrm{mg} / \mathrm{mL}$ diluted with $0.9 \% \mathrm{NaCl}$ in polypropylene syringes stored at $28^{\circ} \mathrm{C}$ protected from light for 48 hours. 


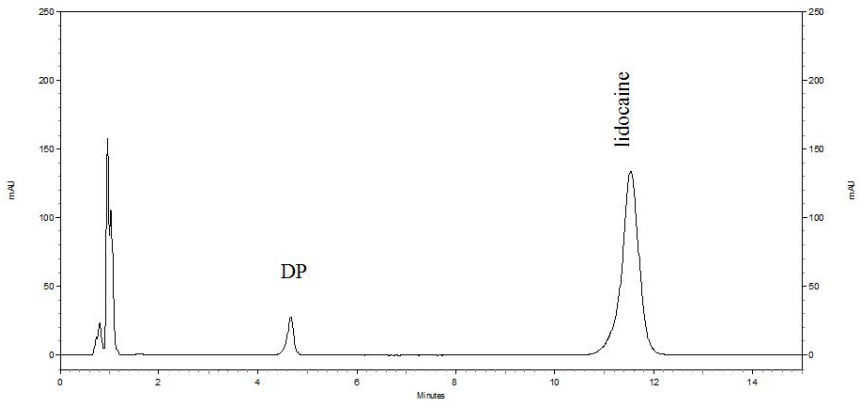

Figure 1 Chromatogram of $200 \mu \mathrm{g} / \mathrm{mL}$ lidocaine in ultrapure water after acidic stressed conditions.

\section{MATERIAL AND METHOD \\ Chemicals and reagents}

Potassium dihydrogenphosphate $\left(\mathrm{KH}_{2} \mathrm{PO}_{4}\right.$, Emsure batch AM0973577 618), sodium hydroxide 30\% (NaOH, VWR chemicals batch $15 \mathrm{~K} 250513$ ) and acetonitrile for HPLC isocratic grade (Carlo erba Reagents batch D8E017238) were used for the mobile phase. Hydrochloric acid 30\% (HCl, VWR chemicals batch 1804003), sodium hydroxide 1M (VWR chemicals batch 17110003), hydrochloric acid 1M (batch $1804003)$ and hydrogen peroxide $30 \%\left(\mathrm{H}_{2} \mathrm{O}_{2}\right.$, Emsure batch K48743810 713) were used. Water for chromatography was obtained from a reverse osmosis system (Millipore Iberica, Madrid, Spain). Lidocaine $50 \mathrm{mg} / \mathrm{mL}$ solution for injection (Aspen batch: 9945375), ketamine $50 \mathrm{mg} / \mathrm{mL}$ solution for injection (Renaudin batch: 205544) and 0.9\% NaCl $500 \mathrm{~mL}$ glass vials (C.D.M Lavoisier batches: 8F461, 8F499 and 8 F495) were used for test solutions, forced degradation and the validation of the analytical method.

\section{Preparation of test solutions}

For the preparation, $2.5 \mathrm{~mL}$ of ketamine $50 \mathrm{mg} / \mathrm{mL}$ and $20 \mathrm{~mL}$ of lidocaine $50 \mathrm{mg} / \mathrm{mL}$ were diluted with $0.9 \% \mathrm{NaCl}$ to obtain a final volume of $50 \mathrm{~mL}$. These solutions were stored in polypropylene syringes (BD Plastipak, $50 \mathrm{~mL}$ Luer-lock). Three

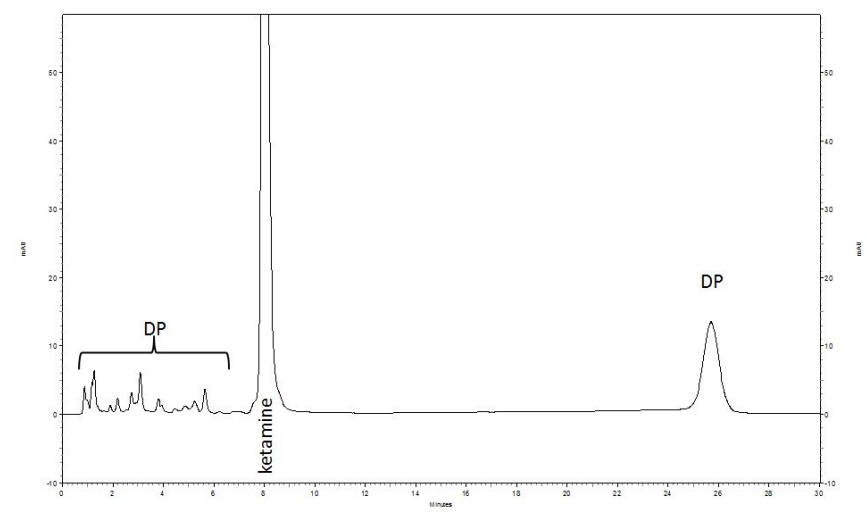

Figure 2 Chromatogram of $250 \mu \mathrm{g} / \mathrm{mL}$ ketamine in ultrapure water after photolytic stressed conditions.

syringes were prepared and were stored at $28^{\circ} \mathrm{C}$, protected from light.

\section{HPLC assay}

Lidocaine and ketamine solutions were analysed by a stabilityindicating reversed-phase high-performance liquid chromatography (RP-HPLC) method with photodiode array detection, adapted from the European Pharmacopoeia (Eur Ph). ${ }^{10}$

The HPLC system consisted of an ELITE LaChrom VWR/ Hitachi plus autosampler, a VWR photodiode array (PDA) detector L-2455 and a VWR L-2130 HPLC-pump. Data was acquired and integrated by using EZChrom Elite (VWR, Agilent). The column used was LiChrospher 100 RP-18, LiChroCART 125-4, length $12.5 \mathrm{~cm}$ and particle size $5 \mu \mathrm{m}$ (Analytical Chromatography, Merck). The mobile phase was $60 \%$ of a phosphate buffer $\mathrm{KH}_{2} \mathrm{PO}_{4}$ at $4.85 \mathrm{~g} / \mathrm{L}$, adjusted at $\mathrm{pH}=8.0 \%$ and $40 \%$ of acetonitrile isocratic grade.

The flow rate was set at $1 \mathrm{~mL} /$ minute, with an injection volume of $20 \mu \mathrm{L}$. The detection wavelength was set at $230 \mathrm{~nm}$. The temperature of the injector was set at $30^{\circ} \mathrm{C}$ and the temperature of the column at $40^{\circ} \mathrm{C}$.

Table 1 Mass balance of lidocaine solutions after various stressed degradations

\begin{tabular}{|c|c|c|c|c|c|c|c|c|}
\hline \multicolumn{9}{|l|}{ Area } \\
\hline \multirow[b]{2}{*}{ Peaks } & \multirow[b]{2}{*}{$\begin{array}{l}\text { Retention } \\
\text { time } \\
\text { (minutes) }\end{array}$} & \multirow[b]{2}{*}{$\begin{array}{l}\text { Relative } \\
\text { retention }\end{array}$} & \multirow[b]{2}{*}{$\begin{array}{l}\text { Without } \\
\text { stressed } \\
\text { degradation }\end{array}$} & \multirow{2}{*}{$\begin{array}{l}\text { Acidic degradation } \\
\\
\mathrm{HCl} \\
30 \% 85^{\circ} \mathrm{C} \\
48 \text { hours }\end{array}$} & \multirow{2}{*}{$\begin{array}{l}\text { Alkaline degradation } \\
\mathrm{NaOH} \\
1 \mathrm{M} \\
85^{\circ} \mathrm{C} \\
48 \text { hours }\end{array}$} & \multirow{2}{*}{$\begin{array}{l}\text { Oxydative degradation } \\
\\
\mathrm{H}_{2} \mathrm{O}_{2} 30 \% 48 \text { hours }\end{array}$} & \multirow{2}{*}{$\begin{array}{l}\text { Heat degradation } \\
85^{\circ} \mathrm{C} \\
48 \text { hours }\end{array}$} & \multirow{2}{*}{$\begin{array}{l}\begin{array}{l}\text { Photolyse } \\
\text { degradation* }\end{array} \\
254 \mathrm{~nm} \\
24 \text { hours }\end{array}$} \\
\hline & & & & & & & & \\
\hline Lidocaine & 11.68 & 1.00 & 14112820 & 13271413 & 12901779 & 12680895 & 14400257 & 1 \\
\hline 2 & 3.75 & 0.32 & & & & 14449 & & 1 \\
\hline 3 & 4.01 & 0.34 & & & & 67051 & & I \\
\hline 4 & 4.32 & 0.37 & & & & 65209 & & 1 \\
\hline 5 & 4.66 & 0.40 & & 1058815 & 38077 & & & I \\
\hline 6 & 7.08 & 0.61 & & & & 15983 & & 1 \\
\hline 7 & 8.64 & 0.74 & & 17057 & & & & 1 \\
\hline
\end{tabular}


Table 2 Mass balance of ketamine solutions after various stressed degradations.

\begin{tabular}{|c|c|c|c|c|c|c|c|c|}
\hline \multicolumn{9}{|l|}{ Area } \\
\hline \multirow[b]{2}{*}{ Peaks } & \multirow[b]{2}{*}{$\begin{array}{l}\text { Retention } \\
\text { time } \\
\text { (minutes) }\end{array}$} & \multirow[b]{2}{*}{$\begin{array}{l}\text { Relative } \\
\text { retention }\end{array}$} & \multirow[b]{2}{*}{$\begin{array}{l}\text { Without } \\
\text { stressed } \\
\text { degradation }\end{array}$} & \multirow{2}{*}{$\begin{array}{l}\begin{array}{l}\text { Acidic } \\
\text { degradation }\end{array} \\
\mathrm{HCl} \\
30 \% 85^{\circ} \mathrm{C} \\
48 \text { hours }\end{array}$} & \multirow{2}{*}{$\begin{array}{l}\begin{array}{l}\text { Alkaline } \\
\text { degradation }\end{array} \\
\mathrm{NaOH} \\
1 \mathrm{M} \\
85^{\circ} \mathrm{C} \\
48 \text { hours }\end{array}$} & \multirow{2}{*}{$\begin{array}{l}\text { Oxydative degradation } \\
\mathrm{H}_{2} \mathrm{O}_{2} 30 \% 48 \text { hours }\end{array}$} & \multirow{2}{*}{$\begin{array}{l}\text { Heat degradation } \\
\\
85^{\circ} \mathrm{C} \\
48 \text { hours }\end{array}$} & \multirow{2}{*}{$\begin{array}{l}\text { Photolyse degradation } \\
254 \mathrm{~nm} \\
3 \text { hours }\end{array}$} \\
\hline & & & & & & & & \\
\hline Kétamine & 7.83 & 1.00 & 13800130 & 13681605 & 12092994 & 13314459 & 14338895 & 12123551 \\
\hline 1 & 1.9 & 0.24 & & & & & & 20538 \\
\hline 2 & 2.2 & 0.28 & & & & 67650 & & 51200 \\
\hline 3 & 2.5 & 0.32 & & & & 33160 & & \\
\hline 4 & 2.75 & 0.35 & & & & & & 46660 \\
\hline 5 & 3 & 0.38 & & & & 157927 & & 139337 \\
\hline 6 & 3.8 & 0.49 & & & & & & 33399 \\
\hline 7 & 4.45 & 0.57 & & & & & & 18708 \\
\hline 8 & 4.9 & 0.63 & & & & & & 18787 \\
\hline 9 & 5.15 & 0.66 & & & 542851 & & & 54982 \\
\hline 10 & 5.65 & 0.72 & & & & & & 128672 \\
\hline 11 & 6.3 & 0.80 & & & 6053 & 9499 & 83063 & 9093 \\
\hline 12 & 6.45 & 0.82 & 11498 & & & & & \\
\hline 13 & 7 & 0.89 & & & & & & 36029 \\
\hline 14 & 25.7 & 3.28 & & & & & & 2015360 \\
\hline \multicolumn{2}{|c|}{ Mass balance } & & 13811628 & 13681605 & 12641898 & 13582695 & 14421958 & 14696316 \\
\hline \multicolumn{3}{|c|}{$\%$ degradation } & & $1 \%$ & $12 \%$ & $4 \%$ & $0 \%$ * & $12 \%$ \\
\hline
\end{tabular}

${ }^{*}$ No degradation was observed for heat degradation. The higher peak surface found is due to the increase of the concentration, probably caused by the evaporation of the solvent.

\section{Lidocaine assay}

The calibration curve was constructed from plots of peak area vs concentration. The linearity of the method was evaluated for five concentrations $(120,160,200,240,280 \mu \mathrm{g} / \mathrm{mL})$. The intra-day reproducibility was evaluated as recommended by International Conference on Harmonisation (ICH) Q2 (R1), using three determinations at $60 \%, 100 \%$ and $140 \%$ of the test concentration (ie, $120 \mu \mathrm{g} / \mathrm{mL}, 200 \mu \mathrm{g} / \mathrm{mL}$ and $280 \mu \mathrm{g} /$ $\mathrm{mL}) .{ }^{11}$ Interday precision was evaluated by repeating the three determinations at the three concentrations previously mentioned for 3 days. ${ }^{12}$

The stability-indicating capability was evaluated by analysing forced degraded lidocaine solutions.

Acidic conditions: a solution of $800 \mu \mathrm{g} / \mathrm{mL}$ lidocaine hydrochloride $1 \mathrm{~mL}$ was diluted with $1 \mathrm{~mL} \mathrm{HCl} 30 \%$ and heated at $85^{\circ} \mathrm{C}$ for 48 hours, neutralised by $1 \mathrm{~mL}$ of $\mathrm{NaOH} 30 \%$ and diluted with $1 \mathrm{~mL}$ of ultrapure water to obtain a theoretical concentration of $200 \mu \mathrm{g} / \mathrm{mL}$.

Alkali degradation: a solution of $800 \mu \mathrm{g} / \mathrm{mL}$ lidocaine hydrochloride $1 \mathrm{~mL}$ was diluted with $1 \mathrm{~mL} \mathrm{NaOH} 1 \mathrm{M}$ and heated at $85^{\circ} \mathrm{C}$ for 48 hours, neutralised by $1 \mathrm{~mL}$ of $\mathrm{HCl} 1 \mathrm{M}$ and diluted with $1 \mathrm{~mL}$ of ultrapure water to obtain a theoretical concentration of $200 \mu \mathrm{g} / \mathrm{mL}$.

Oxidative degradation: a solution of $800 \mu \mathrm{g} / \mathrm{mL}$ lidocaine hydrochloride $1 \mathrm{~mL}$ was diluted with $\mathrm{H}_{2} \mathrm{O}_{2} 3 \% 1 \mathrm{~mL}$ stored at ambient temperature for 48 hours and diluted with $2 \mathrm{~mL}$ of ultrapure water to obtain a theoretical concentration of $200 \mu \mathrm{g} / \mathrm{mL}$.

UV degradation: a solution of $200 \mu \mathrm{g} / \mathrm{mL}$ lidocaine hydrochloride was exposed for 24 hours under a sun-like spectrum lamp at $254 \mathrm{~nm}$ (Vilbert Lourmat).

Heat degradation: a solution of $200 \mu \mathrm{g} / \mathrm{mL}$ lidocaine hydrochloride was exposed to a temperature of $85^{\circ} \mathrm{C}$ for 48 hours.

\section{Ketamine assay}

The calibration curve was constructed from plots of peak area vs concentration. The linearity of the method was evaluated for five concentrations $(150,200,250,300,350 \mu \mathrm{g} / \mathrm{mL})$. The intra-day reproducibility was evaluated as recommended by ICH Q2 (R1),

Table 3 Stability of lidocaine and ketamine diluted in $0.9 \% \mathrm{NaCl}$ over time.

\begin{tabular}{|c|c|c|c|c|c|c|}
\hline \multirow[b]{2}{*}{ Molecule } & \multirow[b]{2}{*}{ Concentration } & \multirow[b]{2}{*}{ Syringe } & \multicolumn{4}{|l|}{ Mean $\%$ of initial concentration $\pm S D * \%$} \\
\hline & & & 0 hour (initial concentration, $\mathrm{mg} / \mathrm{mL}$ ) & 6 hours & 24 hours & 48 hours \\
\hline \multirow[t]{3}{*}{ Lidocaine } & $20 \mathrm{mg} / \mathrm{mL}$ & S1 & $100.00(19,80) \pm 2.14$ & $101.42 \pm 0.19$ & $98.01 \pm 1.93$ & $99.49 \pm 1.14$ \\
\hline & & S2 & $100.00(19.95) \pm 0.80$ & $101.90 \pm 0.33$ & $101.45 \pm 0.33$ & $99.94 \pm 0.20$ \\
\hline & & S3 & $100.00(19.85) \pm 0.34$ & $100.76 \pm 0.86$ & $101.71 \pm 0.82$ & $102.24 \pm 0.26$ \\
\hline \multirow[t]{3}{*}{ Ketamine } & $2.5 \mathrm{mg} / \mathrm{mL}$ & S1 & $100.00(2.45) \pm 0.04$ & $99.29 \pm 1.18$ & $98.71 \pm 1.81$ & $99.44 \pm 1.01$ \\
\hline & & S2 & $100.00(2.46) \pm 0.32$ & $102.63 \pm 0.28$ & $102.15 \pm 0.38$ & $100.52 \pm 0.43$ \\
\hline & & S3 & $100.00(2.47) \pm 0.90$ & $99.84 \pm 1.06$ & $100.22 \pm 0.48$ & $100.42 \pm 0.55$ \\
\hline
\end{tabular}

Drug concentrations in sample taken at time zero were designated at $100 \%$.

*Samples were prepared in triplicate for each syringe. 
using three determinations at $60 \%, 100 \%$ and $140 \%$ of the test concentration (ie, $150 \mu \mathrm{g} / \mathrm{mL}, 250 \mu \mathrm{g} / \mathrm{mL}$ and $350 \mu \mathrm{g} / \mathrm{mL}$ ). Interday precision was evaluated by repeating the three determinations at the three concentrations previously mentioned for 3 days.

The stability-indicating capability was evaluated by analysing forced degraded ketamine solutions.

Acidic conditions: a solution of $1000 \mu \mathrm{g} / \mathrm{mL}$ ketamine hydrochloride $1 \mathrm{~mL}$ was diluted with $1 \mathrm{~mL} \mathrm{HCl} 30 \%$ and heated at $85^{\circ} \mathrm{C}$ for 48 hours, neutralised by $1 \mathrm{~mL}$ of $\mathrm{NaOH} 30 \%$ and diluted with $1 \mathrm{~mL}$ of ultrapure water to obtain a theoretical concentration of $250 \mu \mathrm{g} / \mathrm{mL}$.

Alkali degradation: a solution of $1000 \mu \mathrm{g} / \mathrm{mL}$ ketamine hydrochloride $1 \mathrm{~mL}$ was diluted with $1 \mathrm{~mL} \mathrm{NaOH} 1 \mathrm{M}$ and heated at $85^{\circ} \mathrm{C}$ for 48 hours, neutralised by $1 \mathrm{~mL}$ of $\mathrm{HCl} 1 \mathrm{M}$ and diluted with $1 \mathrm{~mL}$ of ultrapure water to obtain a theoretical concentration of $250 \mu \mathrm{g} / \mathrm{mL}$.

Oxidative degradation: a solution of $1000 \mu \mathrm{g} / \mathrm{mL}$ ketamine hydrochloride $1 \mathrm{~mL}$ was diluted with $\mathrm{H}_{2} \mathrm{O}_{2} 3 \% 1 \mathrm{~mL}$ stored at ambient temperature for 48 hours and diluted with $2 \mathrm{~mL}$ of ultrapure water to obtain a theoretical concentration of $250 \mu \mathrm{g} / \mathrm{mL}$.

UV degradation: a solution of $250 \mu \mathrm{g} / \mathrm{mL}$ ketamine hydrochloride was exposed for 3 hours under a sun-like spectrum lamp at $254 \mathrm{~nm}$ (Vilbert Lourmat).

Heat degradation: a solution of $250 \mu \mathrm{g} / \mathrm{mL}$ ketamine hydrochloride was exposed to a temperature of $85^{\circ} \mathrm{C}$ for 48 hours.

\section{Sample dilution for analysis by RP-HPLC}

The solutions were diluted before analysis with $0.9 \%$ sodium chloride to obtain the concentration of the middle of the standard curve $(200 \mu \mathrm{g} / \mathrm{mL}$ for lidocaine and $250 \mu \mathrm{g} / \mathrm{mL}$ for ketamine).

The diluted solutions were analysed after preparation and after 6, 24 and 48 hours. After dilution, the samples were analysed by RP-HPLC.

Total run time was set at $28 \mathrm{~min}$. A single sample was taken from each syringe each time of the assay.

Chemical stability was defined as not less than 95\% of the initial concentration for both drugs.

\section{pH measurement}

$\mathrm{pH}$ measurement was performed using a Bioblock Scientific $\mathrm{pH}$ meter. Analysis was carried out for each syringe after preparation and after 6, 24 and 48 hours. $\mathrm{pH}$ values were considered to be acceptable if they did not vary by more than $1 \mathrm{pH}$ unit from the initial measurement.

\section{Determination of physical stability}

Physical stability was realised with a visual examination: colour changes and particulate matter every day of the assay. The subvisual aspect was assessed by using a Safas Monaco UV mc2 spectrophotometer. The assay was carried after preparation and after 6, 24 and 48 hours. The absorbance light was scanned at $550 \mathrm{~nm}$. The absorbance of more than 0.010 AU was considered as an evidence of turbidity, providing a quantitative determination of incompatibility. An absorbance reading less than 0.010 AU was considered to be a noise level.

\section{RESULTS}

\section{Reversed phase HPLC}

Lidocaine assay

Under these conditions, the retention time of lidocaine was around $11.5 \mathrm{~min}$. The calibration curve was linear, the correlation coefficient was 0.9998 . The equation of the calibration curve was $y=72950.14750 x-216014.367$. The intra-day precision expressed as relative standard deviation (RSD) ranged between $0.60 \%$ and $2.70 \%$. The inter-day precision expressed as RSD ranged between $1.25 \%$ and $1.57 \%$.

Stability-indicating capacity was proved by using various stressed conditions. A chromatogram obtained after acidic stressed conditions is presented in figure 1 .

The mass balance was evaluated and is presented in table 1 . Area for exclusion limit was established at 5500 .

\section{Ketamine assay}

Under these conditions, the retention time of ketamine was around $8.2 \mathrm{~min}$. The calibration curve was linear, the correlation coefficient was 0.9997 . The equation of the calibration curve was $y=56588.36267 x-94498.733$. The intra-day precision expressed as RSD ranged between $0.27 \%$ and $1.97 \%$. The inter-day precision expressed as RSD ranged between $0.96 \%$ and $1.42 \%$.

Stability-indicating capacity was proved by using various stressed conditions. A chromatogram obtained after photolytic stressed conditions is presented in figure 2 .

The mass balance was evaluated and is presented in table 2 . Area for exclusion limit was established at 5500 .

No peaks of degradation products interfered with the peaks of lidocaine and ketamine. This affirmation is correlated with the peak purities evaluated with EZChrom Elite.

\section{Chemical stability of solutions \\ HPLC assay}

The percentage of lidocaine and ketamine remaining after storage at $28^{\circ} \mathrm{C}$ for various time points is shown in table 3 . After 48 hours, both molecules retained more than $95 \%$ of the initial concentration.

No peak of degradation product was detected during the course of the study.

\section{$\mathrm{pH}$ measurements}

$\mathrm{pH}$ measurements remained stable over the course of the study. The maximum of variation was $0.21 \mathrm{pH}$ unit which is less than our acceptable limit.

\section{Physical stability of solutions \\ Visual aspect}

The solutions of lidocaine mixed with ketamine were clear and colourless. The colour of the solutions did not change over time. No precipitation or gas formation was noted during the study.

\section{Subvisual aspect}

The turbidity of the solutions at $550 \mathrm{~nm}$ was less than $0.010 \mathrm{AU}$ for all three syringes for the duration of the study. The admixtures were physically compatible for 48 hours.

\section{DISCUSSION}

\section{Reversed phase HPLC}

To evaluate the stability indicating capacity of the RP-HPLC method used, forced degradations of lidocaine and ketamine were realised and the mass balance was established for both drugs. The oxidative and alkaline degradations were the most effective for lidocaine. During the study, degrading ketamine with $\mathrm{pH}$ variations, heating or $\mathrm{H}_{2} \mathrm{O}_{2}$ addition was difficult. It has been previously described that ketamine is highly resistant to hydrolysis but sensitive to photolysis. ${ }^{13}$ Our mass balance correlates with this affirmation. 


\section{Stability study}

One limit of our study was the subvisual assessment. Eur Ph 2.9.19 suggest two quantitative methods for the evaluation of non-visible particulates: Method 1 'Light obscuration particle count test' and Method 2 'Microscopic particle count test'. ${ }^{14}$

These two methods allow the counting of the number of particles equal to or greater than $10 \mu \mathrm{m}$ and $25 \mu \mathrm{m}$. Other analytical approaches in Eur $\mathrm{Ph}$ are presented in '2.2.1 Clarity and degree of opalescence of liquids' which suggest two methods: nephelometry, which is the measurement of the light scattered by suspended particles, the measurement usually being made perpendicularly to the incident beam; and turbidimetry which is the measurement of the degree of attenuation of a radiant beam incident on particles suspended in a medium, the measurement being made in the directly transmitted beam. ${ }^{15}$

The International Pharmacopoeia specifies in the chapter 'Physical and Physicochemical Methods, paragraph 1.10 Turbidimetry and nephelometry: 'Turbidity may be measured with a standard photoelectric filter photometer or spectrophotometer, preferably with illumination in the red-orange region of the spectrum (eg, by using a blue filter)., ${ }^{16}$

Turbidimetry and nephelometry have been used in numerous stability studies and Y-site compatibility studies to evaluate the subvisual aspect of physical stability. ${ }^{17}$ In our study, we have used turbidimetry at the visible wavelength $550 \mathrm{~nm}$ suggested by the European Guidelines for the practical stability studies. ${ }^{19}$

However, turbidimetry must be considered as a global measurement of particles suspended in a liquid and does not bring information on the size of the particulates. The Pharmacopoeia approach of paragraph 2.9.19 provides a better level of evidence for the non-visible evaluation of injectable solutions.

Lidocaine hydrochloride $20 \mathrm{mg} / \mathrm{mL}$ and ketamine hydrochloride $2.5 \mathrm{mg} / \mathrm{mL}$ diluted with $0.9 \% \mathrm{NaCl}$ solutions retained respectively $99.98 \% \pm 1.44 \%$ and $100.70 \% \pm 0.95 \%$ after 48 hours' storage at $28^{\circ} \mathrm{C}$ in polypropylene syringes protected from light. The $\mathrm{pH}$ did not vary significantly during the course of the study. Therefore, the limit of stability of lidocaine with ketamine in these conditions is set to 48 hours. The effect of light was not evaluated in this study. The forced degradation realised showed that ketamine is highly sensitive to UV rays. Also, Lin AY et $a l^{20}$ have highlighted that ketamine is sensible to photolysis in river waters.[20] However, Donnelly RF et al demonstrated that ketamine mixed with morphine was stable for 91 days of storage with exposure to light. ${ }^{13}$

\section{Key messages}

What is already known on this subject

- Admixture of lidocaine and ketamine may be used for opioidfree anaesthesia.

- There is no stability data regarding this admixture.

- Stability data is necessary to ensure patients' safety.

What this study adds

- Physicochemical stability was demonstrated for 48 hours.

- This admixture is safe for use for opioid-free anaesthesia protocols.

\section{CONCLUSION}

The physicochemical stability of lidocaine $20 \mathrm{mg} / \mathrm{mL}$ and ketamine $2.5 \mathrm{mg} / \mathrm{mL}$ diluted with $0.9 \% \mathrm{NaCl}$ in polypropylene syringes stored at $28^{\circ} \mathrm{C}$ protected from light was demonstrated for 48 hours. This infusion technique is therefore feasible from a pharmacologic point of view in burn-unit settings.

\section{Twitter Damien Barraud @fluidloading}

Contributors BB: experiments performing, manuscript writing. DB: original idea, proofreading. JV: coordination, proofreading. BD: proofreading.

Funding The authors have not declared a specific grant for this research from any funding agency in the public, commercial or not-for-profit sectors.

Competing interests None declared.

Patient consent for publication Not required.

Provenance and peer review Not commissioned; externally peer reviewed.

Data availability statement Data are available upon reasoned request.

\section{REFERENCES}

1 Manchikanti L, Helm S, Fellows B, et al. Opioid epidemic in the United States. Pain Physician 2012;15(3 Suppl):ES9-38.

2 Agence Nationale de Sécurité du Médicament. État des lieux de la consommation des antalgiques opioïdes et LeuRS usages problématiques. Saint-Denis, 2019. Available: https://ansm.sante.fr/S-informer/Actualite/Antalgiques-opioides-I-ANSM-publie-unetat-des-lieux-de-la-consommation-en-France-Point-d-Information [Accessed 27 Feb 2019].

3 Kamdar NV, Hoftman N, Rahman S, et al. Opioid-free analgesia in the era of enhanced recovery after surgery and the surgical home: implications for postoperative outcomes and population health. Anesth Analg 2017;125:1089-91.

4 Albrecht E, Kirkham KR, Liu SS, et al. Peri-operative intravenous administration of magnesium sulphate and postoperative pain: a meta-analysis. Anaesthesia 2013;68:79-90.

5 ISBI Practice Guidelines Committee, Steering Subcommitte, Advisory Subcommittee. ISBI practice guidelines for burn care. Burns 2016;42:951-2.

6 Stucki MC, Fleury-Souverain S, Sautter AM, et al. Development of ready-to-use ketamine hydrochloride syringes for safe use in post-operative pain. EJHP Science 2008:14:14-18.

7 Huvelle S, Godet M, Hecq J-D, et al. Long-term stability of ketamine hydrochloride $50 \mathrm{mg} / \mathrm{ml}$ injection in $3 \mathrm{ml}$ syringes. Annales Pharmaceutiques Françaises 2016:74:283-7.

8 Storms ML, Stewart JT, Warren FW. Stability of lidocaine hydrochloride injection at ambient temperature and $4^{\circ} \mathrm{C}$ in polypropylene syringes. Int I Pharm Compound 2002;6:388-90.

9 Smith FM, Nuessle NO. Stability of lidocaine hydrochloride in 5\% dextrose injection in plastic bags. Am J Hosp Pharm 1981;38:1745-7.

10 Council of Europe. Lidocaine (chlorhydrate de). In: European Pharmacopoeia. 9th edn. Strasbourg: Council of Europe, 2017: 3114-6.

11 International Conference on Harmonisation: Validation of Analytical Procedures: text and methodology Q2(R1) Guideline, 2005. Available: https://www.ich.org/fileadmin/ Public_Web_Site/ICH_Products/Guidelines/Quality/Q2_R1/Step4/Q2_R1_Guideline. pdf [Accessed 27 Feb 2019].

12 D'Huart E, Vigneron J, Clarot I, et al. Physicochemical stability of norepinephrine bitartrate in polypropylene syringes at high concentrations for intensive care units. Ann Pharm Fr 2019;77:212-21.

13 Donnelly RF. Physical compatibility and chemical stability of ketamine-morphine mixtures in polypropylene syringes. Can J Hosp Pharm 2009;62:28-33.

14 Council of Europe. Contamination particulaire: particules non visibles. In: European Pharmacopoeia. 9th edn. Strasbourg: Council of Europe, 2017: 360-2.

15 Council of Europe. Limpidité et degré d'opalescence des liquides. In: European Pharmacopoeia. 9th edn. Strasbourg: Council of Europe, 2017: 23-4.

16 American Society of Health-System Pharmacists. Handbook on injectable drugs. 19th edn, 2016: 1-1353.

17 World Health Organization. The International Pharmacopoeia. 8th Edn, 2018

18 Staven V, Wang S, Grønlie I, et al. Development and evaluation of a test program for Y-site compatibility testing of total parenteral nutrition and intravenous drugs. Nutr J 2015:15:29.

19 Bardin C, Astier A, Vulto A, et al. Guidelines for the practical stability studies of anticancer drugs: a European consensus conference. Ann Pharm Fr 2011:69:221-31.

20 Lin AY-C, Lee W-N, Wang X-H. Ketamine and the metabolite norketamine: persistence and phototransformation toxicity in hospital wastewater and surface water. Water Res 2014:53:351-60. 